\title{
Penerapan metode pembelajaran kooperatif tipe TGT untuk meningkatkan hasil belajar peserta didik dalam pembelajaran PPKN
}

Rury Kurniawati *, Abdul Gafur Daniamiseno

Program Studi Pendidikan Kewarganegaraan, Pascasarjana, Universitas Negeri Yogyakarta. Jalan Colombo No. 1, Karangmalang, Yogyakarta 55281, Indonesia ruryherliansyah@gmail.com

* Corresponding Author

\section{ARTICLE INFO}

\section{Article History}

Received:

16 Juni 2016;

Revised:

24 September 2019;

Accepted:

26 September 2019

Keywords

Pembelajaran PPKn;

Pembelajaran

kooperatif tipe TGT;

Hasil belajar;

Presentase capaian

KKM;

Pancasila and civic

education;

Cooperative TGT

learning;

Learning outcomes;

Precentage of students

who pass a MCC

\begin{abstract}
ABSTRAK
Penelitian tindakan kelas (PTK) ini bertujuan untuk meningkatkan hasil belajar dan persentase peserta didik yang mencapai kriteria ketuntasan minimal (KKM). Penelitian dilakukan dalam 3 kali siklus pembelajaran. Sebelum dan sesudah pelaksanaan penelitian dilakukan pretest dan posttest untuk mengetahui tingkat pemahaman peserta didik yang tercermin dalam capaian hasil belajar dan jumlah peserta didik yang mencapai KKM. Hasil penelitian menunjukkan rata-rata hasil belajar meningkat dari 82,31 pada siklus ke-1, 87,69 pada siklus ke-2 dan 83,85 pada siklus ke-3. Persentase peserta didik yang mencapai KKM juga mengalami peningkatan mencapai $80,77 \%$ pada siklus ke- $1,88,46 \%$ pada siklus ke- 2 , dan $88,46 \%$ pada siklus ke-3. Dapat disimpulkan bahwa penerapan model pembelajaran kooperatif TGT dapat meningkatkan hasil belajar dan persentase peserta didik Pendidikan Pancasila dan Kewarganegaraan yang mencapai KKM.

The objective of this classroom action research was to improve learning outcomes and the percentage of students who achieve a Minimum Completeness Criterion (MCC). The study was conducted in 3 cycles. Pretest and posttest was done during the process to determine the average learning outcomes and the number of student who pass a MCC. The result showed the average learning outcomes increased from 82.31 in $1^{\text {st }} \mathrm{cycle}$, to 87.69 in $2^{\text {nd }}$ cycle and become 83.85 in $3^{\text {rd }}$ cycle. In addition the percentage of students who pass a MCC reached $80.77 \%$ in $1^{\text {st }}$ cycle, $88.46 \%$ in $2^{\text {nd }}$ cycle and 88.46 $\%$ in $3^{\text {rd }}$ cycle. It can be concluded that, the application of the cooperative learning TGT can improve learning outcomes and percentage of students who pass a MCC of The Pancasila and Civic Education.
\end{abstract}

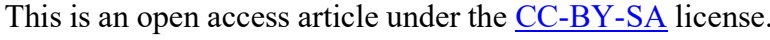

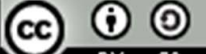




\section{PENDAHULUAN}

Pendidikan Pancasila dan Kewarganegaraan adalah mata pelajaran yang penting dalam pembentukan warga negara agar dapat memahami dan mampu melaksanakan hak-hak dan kewajibannya untuk menjadi warga negara yang cerdas, terampil dan berkarakter kebangsaan. Hal ini mengandung makna bahwa melalui Pendidikan Pancasila dan Kewarganegaraan peserta didik diharapkan mampu untuk memahami, menganalisis dan menjawab masalah-masalah yang dihadapi oleh masyarakat, bangsa dan negaranya secara konsisten dan berkesinambungan (Banks, 2001, p 8; Davies dkk, 2005, p 342-343; Hamidi \& Lutfi, 2010, p. 79). Namun demikian, hasil pengamatan terhadap mata pelajaran Pendidikan Pancasila dan Kewarganegaraan di SMP Islam Terpadu Abu Bakar Yogyakarta menunjukkan, peserta didik terlihat cenderung kurang antusias dalam mengikuti pelajaran tersebut. Sebagian besar peserta didik tampak pasif dan kurang antusias dalam mengikuti pembelajaran, karena selama ini pelajaran Pendidikan Pancasila dan Kewarganegaraan dianggap sebagai pelajaran yang hanya mementingkan hafalan semata, apalagi tidak termasuk salah satu dari pelajaran Ujian Negara.

Berdasarkan angket yang sudah disebarkan kepada peserta didik kelas VII A dan B pada program boarding SMPIT Abu Bakar Yogyakarta, dapat diidentifikasi sejumlah faktor yang mempengaruhi kesuksesan proses belajar dan mengajar, diantaranya: (1) faktor pendidik, pembelajaran yang dilaksanakan seringkali hanya menggunakan metode yang berpusat pada pendidik dan tidak melibatkan aktivitas seluruh peserta didik; (2), faktor metode pembelajaran yang belum menggunakan metode yang bervariasi untuk meningkatkan semangat belajar peserta didik, metode pembelajaran yang digunakan pendidik lebih banyak metode ceramah dan tanya jawab, hal itu sebenarnya tidak selamanya salah, hanya saja dalam beberapa hal, peserta didik menjadi kurang aktif dan monoton dan kurang merasa dilibatkan dalam proses pembelajaran; (3) faktor penggunaan media, dimana media pembelajaran yang digunakan pendidik terkesan belum maksimal sehingga belum mampu menggugah minat peserta didik untuk aktif dan antusias dalam mengikuti proses pembelajaran; (4) faktor pemberian penguatan juga masih kurang diberikan oleh pendidik akibatnya peserta didik cenderung kurang berminat, merasa bosan, dan pasif dalam mengikuti kegiatan pembelajaran yang dilakukan. Selanjutnya, pendidik masih kurang dalam mengembangkan sumber belajar, seharusnya seorang pendidik memiliki sumber belajar yang lebih lengkap dan berkualitas sebagai bahan referensi untuk mempermudah pemahaman dalam memberikan pengetahuan yang lebih luas kepada peserta didik; (5) faktor peserta didik, sebagian besar belum sepenuhnya bertanggungjawab untuk memperhatikan materi pelajaran yang sedang diajarkan. Pada saat proses belajar sedang berlangsung, sebagian peserta didik justru asyik berbicara dengan teman sebangkunya dan mengganggu teman lainnya. Akibatnya, peserta didik kurang memahami materi yang diajarkan. Alasan lain yang mendukung bahwa mereka sudah merasa bisa memahami dengan membaca materi dan mempelajari sendiri. Peserta didik juga cenderung tidak mau mengajukan pertanyaan dari materi yang diajarkan, dan apabila diberi pertanyaan, peserta didik tidak mampu memberikan jawaban atas pertanyaan pendidik dengan baik; (6) faktor kegiatan belajar mengajar (KBM), suasana pembelajaran yang tercipta kurang kondusif, hal tersebut ditunjukkan dengan proses belajar mengajar yang kurang interaktif antara pendidik dan peserta didik, sehingga pembelajaran yang berlangsung terkesan hanya satu arah.

Hal ini tentu saja berpengaruh terhadap hasil belajar atau ketuntasan belajar yang telah ditentukan kriteria ketuntasan minimalnya (KKM). Nilai rata rata ulangan harian yang dicapai peserta didik kelas VII yaitu rata-rata 72,50 dengan jumlah peserta didik yang tuntas sebanyak $66 \%$ padahal KKM di sekolah adalah 78. Hal ini belum mencapai KKM yang telah ditetapkan dan belum tuntas secara klasikal minimal 85\%. Selain itu kondisi di SMP Islam Terpadu Abu Bakar memakai dua program yaitu program boarding school (menginap) dan program fullday school (tidak menginap). Perlu diakui bahwa para peserta didik yang mengambil program boarding pagi harinya sering terlihat mengantuk di dalam kelas, alasan utama yang muncul adalah karena banyak pembelajaran malam dari program kepesantrenan yang sering berakhir sampai larut malam. Kondisikondisi tersebut dirasakan sebagai masalah yang dihadapi pengajar Pendidikan Pancasila dan Kewarganegaraan. 
Untuk mengatasi permasalahan tersebut, diperlukan model pembelajaran yang dapat memberikan makna serta menyenangkan bagi peserta didik. Salah satu model yang dapat mengarahkan peserta didik untuk memperoleh pengalaman belajar secara langsung adalah model pembelajaran kooperatif. Peneliti bersama tim kolaborasi menetapkan alternatif tindakan untuk memperbaiki kualitas pembelajaran Pendidikan Pancasila dan Kewarganegaraan di SMPIT Abu Bakar Yogyakarta dengan menggunakan salah satu model pembelajaran kooperatif tipe Team Game Tournament. Metode pembelajaran kooperatif model Teams-Games-Tournament (TGT) pertama kali dikembangkan oleh DeVries dan Edwards pada tahun 1973 dan selanjutnya dikembangkan oleh DeVries dan Slavin pada tahun 1978 (Garcia dan Esmeralda, 2014, p. 23-24). TGT merupakan metode pembelajaran berbasis kerjasama kelompok untuk mencapai tujuan bersama. Peserta didik belajar untuk saling berkompetisi secara sehat melalui aktivitas yang dilakukan bersama-sama. Salah satu tujuan TGT adalah membentuk suasana belajar yang positif dan menuntut seluruh peserta didik untuk terlibat aktif yang akan membantu terbentuknya kerjasama didalam tim, suasana kompetisi antar tim, dan terbentuknya pengetahuan seiring semakin tingginya keterlibatan dan keatifan peserta didik dalam proses pembelajaran. Menurut VanWyk's (2011, p 191) dan Prastini \& Retnowati (2014, p 177), hasil pembelajaran menunjukkan bahwa metode pembelajaran kooperatif TGT lebih efektif dalam pencapaian prestasi akademik bila dibandingkan dengan metode pembelajaran tradisional. Selain itu TGT merupakan model pembelajaran yang memotivasi peserta didik untuk mendorong dan membantu satu sama lain untuk menguasai keterampilan-keterampilan yang disajikan oleh pendidik.

Hasil penelitian yang dilakukan oleh DeVries dan Edwards (1973) serta DeVries dan Slavin (1978) sebagaimana dikutip dalam Garcia dan Esmeralda (2014, p. 23-24) dan DeVries, dkk. (1975) menunjukkan bahwa TGT akan meningkatkan pencapaian akademik, tingkat kepuasan para peserta didik terhadap pelajaran yang diikutinya, meningkatnya kerjasama diantara para peserta didik, sikap penerimaan diantara para peserta didik dalam satu kelas, dan peningkatan terhadap pemahaman konsep materi pembelajaran yang disampaikan. Para peserta didik memiliki keinginan untuk memenangkan game yang dilaksanakan dalam TGT, sehingga mereka cenderung untuk mempersiapkan diri dengan mempelajari terlebih dahulu materi pelajaran sebelum dilaksanakan proses pembelajaran. Hal tersebut akan membantu para peserta didik untuk mencapai hasil pembelajaran yang lebih baik. Selain itu Garcia dan Esmeralda (2014, p. 23-24) juga mengidentifikasi bahwa TGT dan metode pembelajaran kooperatif berbasis game juga memiliki sejumlah keunggulan diantaranya adalah: 1.) tidak membutuhkan peralatan khusus ataupun bahanbahan yang mahal; 2.) metode tersebut mudah diterapkan dan dapat dilaksanakan dalam waktu pelajaran hanya 45 menit dan dalam berbagai mata pelajaran; 3.) para peserta didik belajar dalam suasana yang informal dan menyenangkan, sehingga para peserta didik tidak akan cepat merasa bosan untuk mengikuti proses belajar; 4.) meningkatkan pencapaian akademik karena proses pembelajaran dilakukan secara lebih menarik sehingga para peserta didik memiliki ketertarikan untuk terlibat didalamnya; 5.) meningkatkan attitude dan tanggung jawab para peserta didik karena mereka terdorong untuk terlibat dalam permainan yang dijalankan dan termotivasi untuk memenangkannya; 6.) meningkatkan kemampuan komunikasi para peserta didik karena saling berdiskusi dalam tim dan saling tukar pengetahuan selama jalannya permainan; 7.) peserta didik dapat segera mengetahui hasil pembelajaran yang telah dicapainya dan dapat segera memperbaiki kesalahan yang telah dilakukannya dalam proses pembelajaran tersebut; dan 8.) membantu terbentuknya positif attitude seperti semangat kerjasama, toleransi dan kemampuan tuntuk menerima pendapat orang lain. Oleh karena itu, penerapan metode TGT di SMPIT Abu Bakar Yogyakarta diharapkan dapat meningkatkan hasil belajar peserta didik dan meningkatkan persentase peserta didik yang memenuhi Kriteria Ketuntasan Minimal (KKM)

\section{METODE}

Penelitian ini merupakan penelitian tindakan kelas dengan menggunakan metode pembelajaran kolaboratif tipe Team Games Tournament (TGT) Penelitian dilaksanakan pada awal tahun pelajaran 2015/2016 yaitu mulai pertengahan bulan Juli sampai dengan September 2015 dengan mengambil lokasi penelitian di kelas VII B SMP Islam Terpadu Abu Bakar Yogyakarta yang 
berada di Jl. Veteran Gg. Bekisar No. 716 Q Pandeyan Umbulharjo Yogyakarta 55161. Populasi dalam penelitian ini adalah peserta didik kelas VII A dan B (kelas program boarding) SMP Islam Terpadu Abu Bakar Yogyakarta tahun pelajaran 2015/2016 yang berjumlah 26 peserta didik. Sedangkan subjek penelitian difokuskan pada kelas VII B. Penelitian ini dilaksanakan dengan mengikuti prosedur yang dikembangkan oleh Kemmis dan McTaggart (Arikunto dkk., 2009) yang dilaksanakan dalam beberapa siklus. Setiap siklus terdiri atas tahapan Perencanaan, Pelaksanaan, Observasi, dan Refleksi seperti ditunjukkan pada Gambar 1.

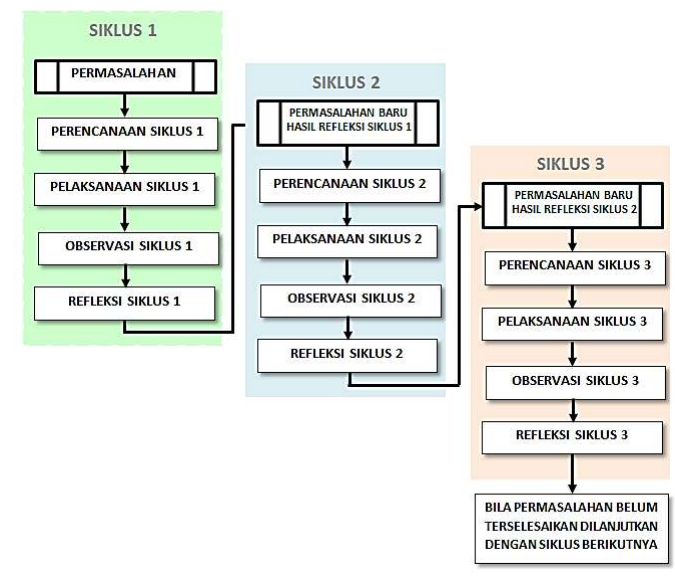

Gambar 1. Model Siklus Penelitian Kemmis dan McTaggart (Arikunto dkk., 2009)

Rancangan pelaksanaan tindakan pada penelitian tindakan kelas dengan menggunakan metode pembelajaran kooperatif tipe TGT dapat dijelaskan secara lebih detil sebagai berikut:

Pra Tindakan

a. Observasi awal

Dilakukan melakukan observasi di kelas VII A dan B (kelas program boarding) SMP IT Abu Bakar pada saat kegiatan pembelajaran PPKn berlangsung.

\section{b. Identifikasi permasalahan}

Dari hasil observasi dilakukan identifikasi permasalahan-permasalahan yang dihadapi pendidik kelas dalam pelaksanaan pembelajaran di kelas VII A dan B (kelas program boarding) SMP IT Abu Bakar pada saat kegiatan pembelajaran PPKn.

\section{c. Mengadakan pretest dan diskusi dengan kontributor}

Setelah melakukan identifikasi masalah, peneliti yang sekaligus merupakan pendidik dikelas tersebut kemudian melakukan pretest mata pelajaran PPKn kepada peserta didik. Hasil yang diperoleh selanjutnya didiskusikan dengan kolaborator (pendidik sebidang) untuk mengetahui pengetahuan awal peserta didik sebelum diberikan tindakan pada mata pelajaran PPKn terutama materi Norma.

\section{d. Menyusun rencana penelitian}

Peneliti sekaligus pendidik bersama kolaborator menyusun rangkaian kegiatan yang akan dilaksanakan pada saat melakukan tindakan kelas secara menyeluruh.

Tindakan Siklus 1

\section{Tahap Perencanaan (Planning) Siklus 1}

Tahapan perencanaan tindakan terdiri atas kegiatan-kegiatan sebagai berikut: (1) menetapkan cara yang akan dilakukan untuk menemukan jawaban, berupa rumusan hipotesis 
tindakan; (2) menentukan cara yang tepat untuk mengkaji hipotesis tindakan; (3) membuat secara rinci rancangan tindakan yang akan dilaksanakan mencakup; (a) bagian isi mata pelajaran dan bahan belajarnya; (b) merancang strategi dan skenario pembelajaran sesuai dengan tindakan yang dipilih; serta (c) menetapkan indikator ketercapaian dan menyusun instrumen pengumpulan data (Trianto, 2011, p 77). Dalam penelitian ini, tahap perencanaannya meliputi sebagai berikut: a) menelaah materi pembelajaran Pendidikan Pancasila dan Kewarganegaraan yang akan dilakukan tindakan penelitian dengan menelaah indikator-indikator pelajaran. b) Menyusun perangkat pembelajaran sesuai indikator dengan menerapkan model TGT, Rencana Pelaksanaan Pembelajaran (RPP), sumber belajar, Lembar Kegiatan Siswa (LKS), kisi-kisi evaluasi, soal evaluasi, dan kunci jawaban. c) Menyiapkan media pembelajaran yang sesuai dengan materi pembelajaran d) Menyiapkan lembar observasi untuk mengamati keterampilan pendidik, aktivitas peserta didik, dan penilaian afektif, serta catatan lapangan. e) Menyiapkan alat dokumentasi atau perekam (foto dan video).

\section{Tahap Tindakan (action) Siklus 1}

Pelaksanaan tindakan pada siklus pertama ini merupakan implementasi dari semua rencana tindakan yang telah dibuat. Langkah-langkah yang dilakukan pendidik tentu saja mengacu pada kurikulum yangm berlaku, dan hasilnya diharapkan berupa perbaikan dan peningkatan afektifitas keterlibatan kolaborator sekedar untuk membantu si peneliti untuk dapat lebih mempertajam refleksi dan evaluasi yang dia lakukan terhadap apa yang terjadi di kelasnya sendiri. Menurut Iskandar (2011, p 117) pelaksanaan tindakan yang telah direncanakan hendaknya cukup fleksibel untuk mencapai perbaikan dan peningkatan yang diinginkan. Dalam penelitian ini, tindakan yang dilakukan dengan menerapkan pembelajaran TGT. Adapun langkah-langkah yang dilakukan dalam tahap ini adalah: (1) melaksanakan kegiatan belajar mengajar sesuai dengan langkah dalam metode TGT dan langkahlangkah yang telah dijelaskan dalam Rencana Pelaksanaan Pembelajaran (RPP); (2) melakukan kegiatan pemantauan proses belajar mengajar melalui observasi langsung; (3) Menyelenggarakan evaluasi untuk mengukur hasil belajar peserta didik.

\section{Tahap Refleksi Tindakan I}

Refleksi dalam penelitian tindakan ini adalah menemukan kelemahan dan memperbaiki di siklus berikutnya, yang dilakukan mulai dari tahap persiapan sampai pelaksanaan tindakan. Refleksi dilaksanakan agar tidak terjadi kesalahan yang terulang pada siklus berikutnya. Pada tahap ini dilakukan analisis pelaksanaan proses kegiatan belajar mengajar. Langkah-langkah dalam kegiatan analisis dapat dilakukan diantaranya yaitu sebagai mencocokkan hasil pengamatan oleh pendidik pada lembar observasi. Apabila hasil pengamatan ternyata peserta didik mengikuti pelajaran dengan antusias yaitu peserta didik aktif, perhatian peserta didik tertuju pada pelajaran, peserta didik merespon dan terjadi komunikasi dua arah, maka model kegiatan belajar mengajar yang dilaksanakan dinyatakan menarik dan dapat meningkatkan kualitas proses pembelajaran. Setelah tahap refleksi maka kelemahan dalam pembelajaran di siklus I diperbaiki dalam siklus berikutnya, yaitu siklus II. Dari keberhasilan dan kegagalan dalam pelaksanaan tindakan yang tertuang dalam refleksi maka peneliti dengan pendidik mengadakan diskusi untuk mengambil kesepakatan menentukan tindakan perbaikan berikutnya dalam proses kegiatan belajar mengajar yang dilaksanakan oleh peneliti.

Data, Intrumen, dan Teknik Pengumpulan Data

Data yang diperoleh dalam penelitian tindakan kelas ini adalah data kuantitatif berupa hasil tes dan data kualitatif berupa uraian hasil pengamatan. Selain itu, sebagai kelengkapan data maka disertai data dokumentasi berupa foto-foto kegiatan dalam penelitian. Instrumen yang digunakan oleh peneliti berupa soal tes dan lembar observasi. Soal tes pada siklus 1 hingga siklus 3 terdiri dari 10 soal pilihan ganda. Sedangkan lembar observasi untuk peserta didik berjumlah 10 butir. Teknik pengumpulan data yang digunakan oleh peneliti adalah sebagai berikut:

\section{Tes Hasil Belajar}

Tes diberikan setiap awal dan akhir siklus yang digunakan untuk menunjukkan hasil belajar yang dicapai pada setiap siklus. Penelitian ini menggunakan tes bentuk pilihan ganda bejumlah 10 
soal. Tes ini digunakan untuk mengumpulkan data hasil belajar peserta didik sebelum dan setelah pembelajaran dengan menggunakan model pembelajaran kooperatif tipe TGT.

\section{Observasi}

Teknik observasi yang digunakan dalam penelitian ini adalah observasi sistematis dengan menggunakan lembar observasi sebagai pedoman pengamatan. Observasi dilakukan oleh peneliti dan kontributor terhadap peserta didik dengan cara melakukan pengamatan dan pencatatan mengenai pelaksanaan pembelajaran PPKn dengan TGT di kelas selama proses belajar mengajar berlangsung.

\section{Teknik Analisis Data}

Data hasil belajar, serta pengamatan terhadap keaktifan peserta didik selama proses pembelajaran menggunakan metode TGT, diolah dan dianalisis secara kualitatif. Berdasarkan data yang telah terkumpul, maka dilakukan analisis dan refleksi terhadap hasil dan proses tindakan yang telah dilakukan. Analisis tersebut dilakukan dengan cara membandingkan hasil tindakan dengan indikator kinerja yang diterapkan seperti ditunjukkan pada Tabel 1. Jika hasil tindakan lebih baik atau sama dengan indikator yang telah diterapkan, maka penelitian tindakan kelas ini dinilai berhasil. Jika hasilnya lebih rendah atau lebih jelek, maka penelitian tindakan ini ditetapkan belum berhasil, dan selanjutnya dilakukan perbaikan ulang dalam siklus kegiatan kedua dan seterusnya sampai tindakan berhasil.

Tabel 1. Kriteria Keberhasilan Tindakan Kelas

\begin{tabular}{clc}
\hline No. & \multicolumn{1}{c}{ Aspek yang dinilai } & Target \\
\hline 1. & Nilai Ketuntasan Minimal & 78 \\
2. & Ketuntasan Klasikal (Persentase Peserta didik KKM Dalam Satu Kelas) & $85 \%$ \\
\hline
\end{tabular}

\section{HASIL DAN PEMBAHASAN}

Rangkuman hasil proses pembelajaran sebelum dan setelah melaksanakan TGT pada siklus 1 ditampilkan pada Tabel 2. Dalam tabel tersebut ditunjukkan data nilai sebelum pembelajaran dengan metode TGT dan setelah pelaksanaan pembelajaran dengan metode TGT. Berdasarkan hasil pekerjaan peserta didik sebelum dilaksanakan proses pembelajaran dengan metode TGT, dapat diidentifikasi bahwa rata-rata nilai yang dicapai peserta didik hanya 53,46 dengan nilai tengah (median) 50 dan sebaran nilai (modus) sebesar 40, hal ini disebabkan peserta didik masih kesulitan memahami tersebut. Setelah dilaksanakan proses pembelajaran dengan TGT terlihat bahwa rata-rata nilai peserta didik mencapai 82,31 dengan nilai tengah (median) 80 dan nilai yang paling sering muncul (modus) sebesar 80. Dari Tabel 2 juga dapat diperoleh informasi tingkat ketuntasan pembelajaran yang dilakukan sebelum menerapkan TGT dan setelah menerapkan TGT pada siklus 1 ini seperti dirangkum dalam Gambar 2. Pada Gambar 2. hasil belajar sebelum dilaksanakan pembelajaran dengan metode TGT ditandai dengan marker belah ketupat $(\diamond)$ dan setelah dilakukan proses pembelajaran dengan metode TGT ditandai dengan marker berupa segi empat (ם) yang ditempatkan dalam sebuah diagram radar. Dari Gambar 2. terlihat sebagian besar peserta didik atau 21 anak $(76,92 \%$ ) belum dapat mencapai batas nilai KKM (masih banyak marker belah ketupat $(\bullet)$ ) yang berada diluar garis batas KKM. Hanya $5(23,08 \%)$ peserta didik yang memenuhi nilai KKM Setelah diterapkan metode TGT pada siklus 1 terlihat jumlah peserta didik yang prestasi belajarnya diatas garis batas KKM naik dengan signifikan (80,77\%) atau sebanyak 21 peserta didik.

Berdasarkan hasil refleksi pada siklus 1 maka dilakukan perencanaan untuk pelaksanaan tindakan pada siklus 2. Peneliti membuat RPP untuk siklus 2 dengan materi yang berbeda dari materi pada siklus 2, yaitu Tujuan Pelaksanaan Norma Agama, Kesusilaan, Contoh Pelaksanaan Norma Agama, Kesusilaan, Kesopanan, Hukum dan Contoh Alasan Penyebab Pelanggaran Norma, Kesopanan, Hukum. Jika pada siklus 1 peserta didik diberi tugas kelompok untuk mendiskusikan suatu kasus, pada siklus 2 ini peserta didik diberi lembar kerja peserta didik (LKS) untuk menjawab pertanyaan-pertanyaan dari pendidik. 
Tabel 2. Hasil Pembelajaran Pada Siklus 1

\begin{tabular}{lccc}
\hline \multicolumn{1}{c}{ Siklus 1 } & Hasil pembelajaran & \\
& Pretest & Posttest & Selisih \\
\hline Rerata & 53.46 & 82.31 & \\
Standart Deviasi & 19.58 & 12.75 & \\
Median & 50.00 & 80.00 & \\
Modus & 40.00 & 80.00 & \\
Nilai Diatas KKM & $23,08 \%$ & $80,77 \%$ & \\
Nilai Dibawah KKM & $76,92 \%$ & $19,23 \%$ & \\
\hline
\end{tabular}

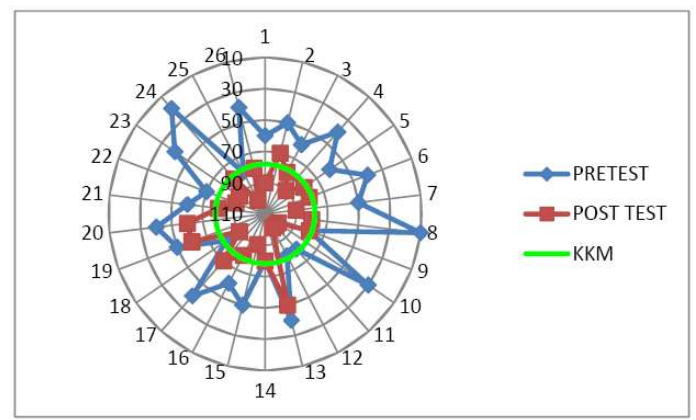

Gambar 2 Sebaran Nilai Pretest dan Posttest Siklus 1 Kelas VII B

Tindakan pada siklus 2 pada umumnya sama dengan tindakan pada siklus 1, tetapi lebih difokuskan untuk penyempurnaan dan perbaikan terhadap kendala-kendala yang muncul pada siklus 1. Adapun tindakan yang dimaksud adalah sebagai berikut: pertama, pada siklus 1 peserta didik belum terbiasa mengikuti pembelajaran dengan metode Teams Game Tournament (TGT) selanjutnya pendidik memberikan arahan kembali kepada peserta didik bagaimana seharusnya mereka dalam mengikuti pembelajaran. Kedua, pendidik menegaskan kembali bahwa tugas kelompok harus dilakukan secara bersama-sama. Ketiga, mendorong peserta didik yang masih enggan dan malu dalam mengajukan maupun menjawab pertanyaan serta masih kurang berpartisipasi aktif dalam melakukan kegiatan diskusi untuk lebih aktif lagi sebelum turnamen berlangsung.

Pada siklus kedua ini dilakukan pengukuran hasil belajar sebelum dilaksanakan siklus kedua dan setelah dijalankannya metode pembelajaran kooperatif dengan tipe TGT. Rangkuman hasil pengukuran tersebut ditampilkan dalam Tabel 3.

Tabel 3. Hasil Pembelajaran Pada Siklus 2

\begin{tabular}{lccc}
\hline \multicolumn{1}{c}{ Siklus 2 } & & Hasil pembelajaran & Selisih \\
\hline Rerata & Pretest & Posttest & 30.00 \\
Standart deviasi & 57.69 & 87.69 & \\
Median & 15.05 & 11.42 & \\
Modus & 55.00 & 90.00 & \\
Nilai diatas kkm & 50.00 & 90.00 \\
Nilai dibawah kkm & 7.69 & 88.46 & \\
\hline
\end{tabular}

Dari Tabel 3 tampak bahwa pada siklus 2 rata-rata prestasi belajar peserta didik sebelum dijalankan metode pembelajaran kooperatif tipe TGT (pretest) mencapai nilai 57,69 dengan nilai tengah (median) 55 dan nilai yang paling sering muncul (modus) adalah 50. Nilai ini lebih tinggi bila dibandingkan dengan hasil pretest pada siklus 1 . Kondisi ini menunjukkan bahwa walaupun TGT belum dilaksanakan peserta didik sudah mulai mempersiapkan diri sebelum pelaksanaan pembelajaran PPKn karena berharap bahwa seandainya nantinya akan dilakukan kegiatan kompetisi 
mereka dapat memenangkannya. Setelah dijalankan proses pembelajaran dengan TGT terlihat pada Tabel 3. terjadi kenaikan rata-rata nilai secara signifikan menjadi 87,69 dengan nilai tengah (median) 90 dan nilai yang paling sering muncul (modus) 90. Dari data dalam Tabel 3. juga diperoleh informasi jumlah peserta didik yang mampu mencapai ketuntasan dalam belajar sebelum penerapan TGT dan setelah penerapan TGT pada siklus 2 yang dapat ditampilkan dalam Gambar 3.

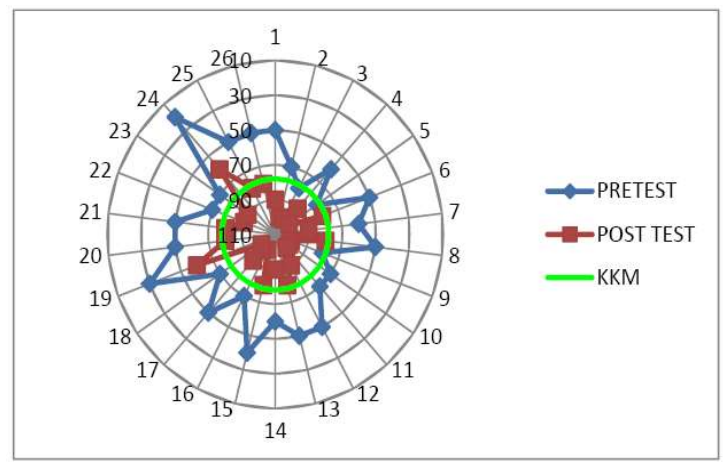

Gambar 3 Sebaran Nilai Pretest dan Posttest Siklus 2 Kelas VII B

Pada Gambar 3. hasil belajar sebelum dilaksanakan pembelajaran dengan metode TGT ditandai dengan marker belah ketupat $(\diamond)$ dan setelah dilakukan proses pembelajaran dengan metode TGT ditandai dengan marker berupa segi empat ( $)$ yang ditempatkan dalam sebuah diagram radar. Dari Gambar 3. terlihat sebagian besar peserta didik atau 23 anak $(92,31 \%)$ belum dapat mencapai batas nilai KKM (masih banyak marker belah ketupat $(\diamond)$ ) yang berada diluar garis batas KKM. Hanya 3 (7,69\%) peserta didik yang memenuhi nilai KKM Setelah diterapkan metode TGT pada siklus 2 terlihat jumlah peserta didik yang prestasi belajarnya diatas garis batas KKM naik dengan signifikan $(88,46 \%)$ atau sebanyak 24 peserta didik.

Gambar 3. tersebut juga menunjukkan terjadinya peningkatan jumlah peserta didik yang memenuhi standart KKM setelah penerapan metode TGT bila dibandingkan dengan pelaksanaan siklus 1 yang sebelumnya $80,77 \%$ menjadi $88,46 \%$. Hasil ini menunjukkan peserta didik sudah relative lebih siap bila dibandingkan dengan siklus sebelumnya. Peserta didik yang sampai dengan siklus 2 ini belum sempurna dalam menyelesaikan soal yang diberikan, karena peserta didik tersebut masih kesulitan dengan materi pelaksanaan norma agama, kesusilaan, kesopanan, hukum, contoh pelaksanaan norma agama, kesusilaan, kesopanan, hukum.

Dari pelaksanaan dua siklus tersebut sudah menunjukkan peningkatan hasil belajar dan target persentase siswa yang mencapai KKM sudah tercapai. Namun demikian peneliti dan kolaborator memutuskan untuk menjalankan siklus yang ke-3 karena karakteristik materi pada siklus ke-3 berbeda dengan dua siklus terdahulu, yaitu peserta didik dituntut untuk mampu mendeskripsikan sikap positif terhadap pelaksanaan norma agama, kesusilaan, kesopanan, hukum. Hal ini sekaligus untuk melihat apakah metode pembelajaran TGT dapat digunakan untuk seluruh jenis topik materi pembelajaran. Rangkuman evaluasi terhadap hasil belajar peserta didik sebelum pelaksanaan siklus 3 dan setelah siklus 3 ditampilkan dalam Tabel 4.

Tabel 4. Hasil Pembelajaran Pada Siklus 3

\begin{tabular}{lccc}
\hline \multicolumn{1}{c}{ Siklus 3 } & & Hasil pembelajaran & Selisih \\
\hline Rerata & Pretest & Posttest & 21.92 \\
Standart Deviasi & 61.92 & 83.85 & \\
Median & 8.01 & 7.11 & \\
Modus & 60.00 & 85.00 \\
Nilai Diatas KKM & 60.00 & 90.00 \\
Nilai Dibawah KKM & 3.85 & 88.46 \\
\hline
\end{tabular}


Dari Tabel 4. tampak bahwa pada siklus 3 rata-rata prestasi belajar peserta didik sebelum dijalankan metode pembelajaran kooperatif tipe TGT (pretest) mencapai nilai 61,92 dengan nilai tengah (median) 60 dan nilai yang paling sering muncul (modus) adalah 60. Nilai ini lebih tinggi bila dibandingkan dengan hasil pretest pada siklus 1 dan siklus 2 . Kondisi ini menunjukkan bahwa walaupun TGT belum dilaksanakan peserta didik sudah mempersiapkan diri sebelum pelaksanaan pembelajaran PPKn dengan kata lain peserta didik di kelas VII B sudah mempersiapkan diri dengan belajar sebelum mengikuti proses pembelajaran PPKn. Namun setelah dijalankan proses pembelajaran dengan TGT terlihat pada Tabel 3. justru nilai rata-rata hasil belajar justru mengalami penurunan bila dibandingkan dengan siklus 2, yaitu hanya mencapai 83,85 dengan nilai tengah (median) 85 dan nilai yang paling sering muncul (modus) 90. Sedangkan dari tingkat ketuntasan capaian pembelajaran antara sebelum dijalankan siklus 3 dan setelah dijalankan siklus 3 dengan metode TGT disajikan dalam Gambar 4.

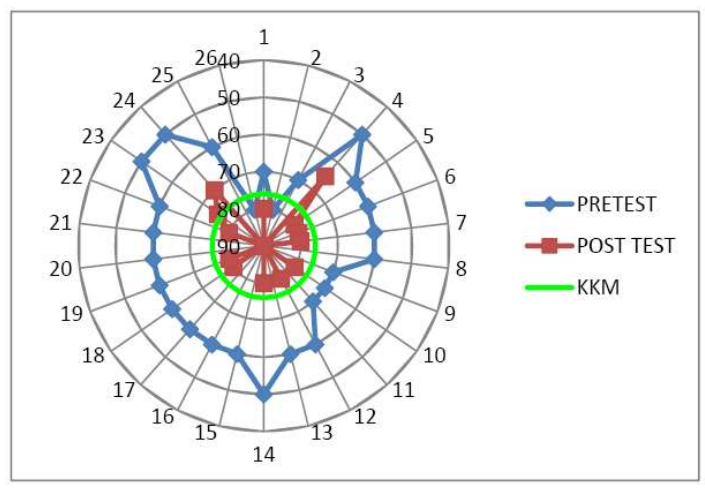

Gambar 4 Sebaran Nilai Pretest dan Posttest Siklus 3 Kelas VII B

Pada Gambar 4. hasil belajar sebelum dilaksanakan pembelajaran dengan metode TGT ditandai dengan marker belah ketupat $(\diamond)$ dan setelah dilakukan proses pembelajaran dengan metode TGT ditandai dengan marker berupa segi empat ( $)$ yang ditempatkan dalam sebuah diagram radar. Dari Gambar 4. terlihat sebagian besar peserta didik atau 24 anak $(96,15 \%)$ belum dapat mencapai batas nilai KKM (masih banyak marker belah ketupat $(\diamond)$ ) yang berada diluar garis batas KKM. Hanya $2(3,85 \%)$ peserta didik yang memenuhi nilai KKM. Padahal batas KKM untuk KD 3 ini hanya 76, lebih rendah dari KD1 dan KD 2 pada siklus 1 dan siklus 2. Kondisi menunjukkan penurunan bila dibandingkan dengan pencapaian KKM pada siklus sebelumnya. Setelah diterapkan metode TGT pada siklus 3 terlihat jumlah peserta didik yang prestasi belajarnya diatas garis batas KKM naik dengan signifikan $(88,46 \%)$ atau sebanyak 24 peserta didik.

Hasil penerapan metode TGT pada siklus ke-3 pada Gambar 4. menunjukkan bahwa jumlah peserta didik yang dapat memenuhi standart KKM relative sama dengan siklus sebelumnya hal tersebut menunjukkan kondisi yang sudah stabil antara siklus ke-2 dan ke-3. Untuk perbaikan lebih lanjut diperlukan modifikasi dalam metode TGT (jenis permainan, atau media yang digunakan) agar menciptakan kondisi belajar yang dinamis, kreatif dan menarik bagi seluruh peserta didik. Kreativitas pendidik dituntut untuk selalu diasah agar menghasilkan suasana belajar yang menarik. Peserta didik yang belum sempurna dalam menyelesaikan soal-soal yang diberikan, terjadi karena peserta didik merasa kesulitan dengan materi KD 3 yang sifatnya mendeskripsikan sikap positif terhadap pelaksanaan norma agama, kesusilaan, kesopanan, hukum. Dalam pembelajaran siklus 3, peserta didik sudah mulai terbiasa dalam mengikuti pembelajaran dengan metode TGT. Peserta didik juga telah berusaha lebih mempersiapkan diri dengan belajar sehingga nilai pretestnya semakin meningkat dari siklus 1 hingga siklus 3 . Namun demikian dari sisi pelaksanaan pembelajaran dengan metode pembelajaran kooperatif tipe TGT terlihat antara siklus 1 dan siklus 2 meningkat dengan signifikan, namun justru menurun di siklus ke-3. Kondisi tersebut dapat dilihat pada Gambar 5. 


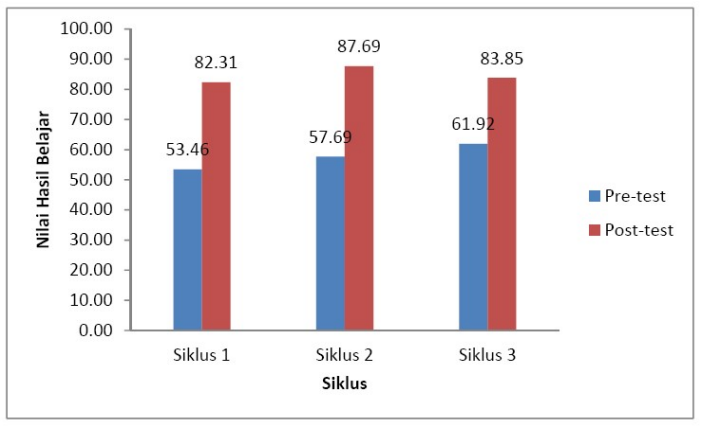

Gambar 5. Perbandingan Pencapaian Hasil Belajar Antar Siklus

Dari sisi efektifitas metode pembelajaran yang dilihat dari persentase peserta didik yang memenuhi standart ketuntasan belajar dalam setiap siklus untuk kelas VII B SMP IT Abu Bakar Yogyakarta ditunjukkan pada Gambar 6. Pada gambar tersebut ditunjukkan bahwa setelah diterapkannya metode TGT tingkat ketuntasan pembelajaran dalam kelas yang pada awalnya hanya $80,77 \%$ pada siklus ke- 1 , yang berarti belum mencapai standart ketuntasan kelas atau metode pembelajaran yang efektif dan efisien, namun naik menjadi $88,46 \%$ pada siklus yang ke-2 dan tetap stabil pada angka yang sama pada siklus ke-3.

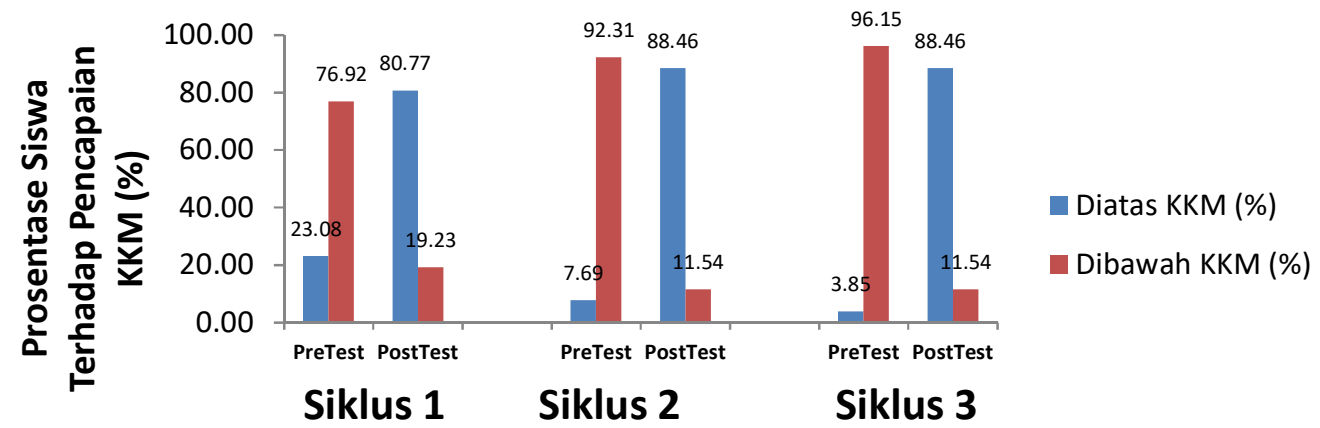

Gambar 6. Perbandingan Persentase Nilai Pretest dan Posttest Yang Dibawah KKM dan Diatas KKM Pada Setiap Siklus Di Kelas VII B

Gambar 6. menunjukkan bahwa metode TGT telah berhasil diterapkan untuk memperbaiki situasi pembelajaran PPKn pada kelas VII program boarding school di SMP IT Abu Bakar Yogyakarta pada siklus 1 dan siklus 2. Namun tidak semua kegiatan belajar dapat diselesaikan dengan metode pembelajaran kooperatif tipe TGT. Pada siklus 3 tidak terjadi peningkatan hasil belajar, namun justru menurun. Untuk meningkatkan capaian tersebut perlu dilakukan perubahan dan inovasi pada jenis/tipe kegiatan pembelajaran kooperatif atau perubahan pada jenis kegiatan permainan (game) yang akan digunakan agar suasana belajar tetap terasa menarik bagi seluruh peserta didik. Dapat disimpulkan bahwa penerapan metode TGT tidak berhasil meningkatkan hasil belajar peserta didik kelas VII B SMPIT Abu Bakar Yogyakarta pada KD 3 pembelajaran PPKn yang bersifat mendeskripsikan sikap positif terhadap pelaksanaan norma agama, kesusilaan, kesopanan, hukum tidak berhasil meningkatkan hasil belajar peserta didik seperti dirangkum dalam Tabel 5.

Tabel 5. Perbandingan keberhasilan tindakan terhadap hasil belajar

\begin{tabular}{cccccc}
\hline \multirow{2}{*}{ No. } & \multirow{2}{*}{ Aspek yang dinilai } & Target & Siklus 1 & Pencapaian Target \\
Siklus 2 & Siklus 3 \\
\hline
\end{tabular}




\begin{tabular}{cccccc}
\hline 1. & Nilai ketuntasan & 78 & 82,31 & 87,69 & $83,85^{*}$ \\
2. & Ketuntasan kelas & $85 \%$ & 80,77 & 88,46 & 88,46 \\
\hline
\end{tabular}

Catatan *) Nilai ketuntasan KD 3 pada siklus $3=76$

Penerapan pembelajaran kooperatif metode team game tournament (TGT) dalam suatu pembelajaran apabila dilaksanakan secara maksimal dapat meningkatkan hasil belajar peserta didik. Penerapan metode TGT bertujuan untuk melibatkan aktivitas seluruh peserta didik tanpa harus ada perbedaan status, melibatkan peran peserta didik sebagai tutor sebaya dan mengandung unsur permainan. Aktivitas belajar dengan permainan yang dirancang dalam pembelajaran kooperatif model TGT memungkinkan peserta didik dapat belajar lebih rileks disamping menumbuhkan, keterlibatan belajar. Tujuan utamanya adalah peningkatan hasil belajar kelompok dalam suatu tim sebagai persiapan menghadapi turnamen yang dipersiapkan antar kelompok dengan pola permainan yang dirancang oleh pendidik. Penerapan metode Team Game Tournament (TGT) pada pembelajaran PKn pada peserta didik kelas VII B SMPIT Abu Bakar Yogyakarta secara umum menunjukkan adanya peningkatan hasil belajar peserta didik.

Namun demikian penelitian yang dilaksanakan ini masih terbatas pada kelas program boarding saja sedangkan kelas dengan program fullday yang memiliki karakteristik program pembelajaran dan suasana belajar yang berbeda bagi para peserta didiknya belum dicobakan dan diamati. Selain itu dalam penelitian ini juga tidak diamati pengaruh sebaran peserta didik yang memiliki prestasi akademik yang tinggi dalam kelompok-kelompok peserta permainan. Seluruh peserta permainan dibagi secara acak tanpa melihat latar belakang prestasi akademiknya sehingga terdapat kemungkinan peserta didik dengan latar belakang prestasi akademik yang kurang atau yang menonjol akan berkumpul dalam satu kelompok. Dari penelitian yang dilakukan juga diketahui bahwa metode pembelajaran kooperatif tipe TGT tidak cocok untuk seluruh materi pembelajaran. Oleh karena itu perlu diamati lebih detil karakteristik materi pembelajaran (KD) yang sesuai dengan metode TGT dan yang tidak sesuai agar dapat menerapkan etode yang tepat untuk setiap topik pembelajaran sehingga diperoleh hasil pembelajaran yang maksimal.

\section{SIMPULAN}

Berdasarkan hasil penelitian dan pembahasan pada bab IV, maka dapat disimpulkan bahwa terdapat kenaikan rata-rata hasil belajar peserta didik kelas VII setelah diterapkannya metode pembelajaran TGT dari rata-rata 53,46 menjadi 82,31 (meningkat sebesar 28,85 ) pada siklus 1 , kemudian dari rata-rata 57,69 menjadi 87,69 (meningkat sebesar 30) pada siklus 2, dan dari rata-rata 61,92 menjadi 83,85 (meningkat sebesar 21,92) pada siklus 3. Selain itu persentase peserta didik yang mencapai KKM pada kelas VII setelah diterapkannya metode pembelajaran kooperatif model TGT meningkat dari $66 \%$ menjadi $80,77 \%$ pada siklus ke- 1 . Karena belum mencapai target sebesar $85 \%$ maka dilanjutkan dengan siklus ke-2 dan diperoleh peningkatan menjadi $88,46 \%$ pada siklus ke-2 dan tetap sebesar $88,46 \%$ pada siklus ke-3.

\section{DAFTAR PUSTAKA}

Arikunto, S., Suhardjono, S., \& Supardi, S. (2009). Penelitian tindakan kelas. Jakarta: Bumi Aksara.

Banks, J. A. (2001) Citizenship Education and Diversity: Implications for Teacher Education, Journal of Teacher Education, 52, 5-16. doi:https://doi.org/10.1177/0022487101052 001002

Davies, I., Gorard, S., \& McGuinn, N. (2005). Citizenship education and character education: similarities and contrasts. British Journal of Educational Studies, 53(3). 341-358.

DeVries, D. L., Mescon, I. T., \& Shackman, S. L. (1975). Teams-games-tournament in the elementary classroom: A replication, center for social organization of schools. Maryland: The Johns Hopkins University. 
García, V., \& Esmeralda, M. (2014, 22 June). Knowledge competition: An entertaining and useful way to review concepts that would enable students to develop other underlying skills. XI Jornadas Internacionales de Innovación Universitaria "Educar Paratransformar", Madrid, Spain.

Hamidi, J., \& Lutfi, M. (2010), Civic education: antara realitas politik dan implementasi. Jakarta: Gramedia Pustaka Utama.

Iskandar, I. (2011). Penelitian tindakan kelas. Jakarta: Gaung Persada.

Prastini, M., \& Retnowati, T. (2014). Peningkatan keterampilan sosial dan hasil belajar IPS melalui model kooperatif TGT di SMPN 1 Secang. Harmoni Sosial: Jurnal Pendidikan IPS, 1(2), 165-178. doi:https://doi.org/10.21831/hsjpi.vli2.2438

Trianto, T. (2011). Penelitian tindakan kelas. Jakarta: Prestasi Pustaka

Van Wyk, M. M. (2011). The effects of teams-games-tournaments on achievement, retention, and attitudes of economics education students. Journal Social Science, 26(3), 183-193. 